\title{
Pemberian oral ekstrak kulit buah lemon (Citrus limon) menghambat peningkatan ekspresi MMP-1 (matrix metaloproteinase-1) dan penurunan jumlah kolagen pada tikus putih galur wistar jantan (Rattus norvegicus) yang dipajan sinar UV-B
}

\author{
${ }^{1}$ Ahmad M. Anshori \\ ${ }^{2}$ Anak A. G. P. Wiraguna \\ ${ }^{3}$ Wimpie Pangkahila
}

\author{
${ }^{1}$ Program Pascasarjana Anti-Aging Medicine \\ ${ }^{2}$ Departemen Penyakit Kulit dan kelamin, \\ ${ }^{3}$ Departemen Andrologi dan Seksologi \\ Fakultas Kedokteran Universitas Udayana \\ Email: amet_bj2005@yahoo.com
}

\begin{abstract}
Ultraviolet B (UVB) is a source of free radicals that accelerate aging process of the skin such as activating enzymes that degrade collagen and inhibit collagen production by inducing the expression of MMP-1. Lemon peel contains vitamin C, vitamin A, tannins and phenols which possess antioxidant activity and prevent oxidative stress. This study was aimed to prove that oral administration of lemon peel extract could decrease MMP-1 levels and increase the number of collagen in the UVB-induced male Wistar rats (Rattus norvegicus). This was a true experimental study with the post test only control group design. Subjects were 30 male Wistar rats (Rattus norvegicus), aged 2-3 months, body weight $120 \mathrm{~g}$, divided into 3 groups, as follows: the control group (P0) which were not exposed to UVB; the treatment group 1 (P1) given aquabidest and UVB ray exposure; and the treatment group 2 (P2) given lemon peel extract and UVB ray exposure. After 15 days of treatment, all rats were anesthetized and their skin tissues were prepared for histological examination of MMP1 and collagen. The results showed that the average expression of MMP1 in P0 group was $22.02 \pm 3.20 \%$; in the P1 group was $29.04 \pm 6.36 \%$; and in $\mathrm{P} 2$ group was $7.98 \pm 2.76 \%(P<0.01)$. In addition, the average amount of collagen in P0 group was $70.01 \pm 2.99 \%$; in the P1 group was $57.68 \pm 4.84 \%$; and in P2 group was $77.45 \pm 4.29 \%$ $(P<0.01)$. Conclusion: Oral administration of lemon peel extract could decrease the expression of MMP-1 and increase the amount of collagen in the UVB-induced male Wistar rats (Rattus norvegicus).
\end{abstract}

Keywords: lemon peels, collagen, MMP-1, UVB

\begin{abstract}
Abstrak: Ultraviolet B (UVB) merupakan sumber radikal bebas yang mempercepat proses penuaan kulit dengan mengaktivasi enzim yang mendegradasi kolagen dan menghambat produksi kkolagen melalui induksi ekspresi MMP-1. Kulit buah lemon mengandung vitamin C, vitamin A, tanin, dan fenol yang memiliki aktivitas antioksidan dan mencegah stres oksidatif. Penelitian ini bertujuan untuk membuktikan bahwa pemberian ekstrak kulit buah lemon per oral dapat menurunkan kadar MMP-1 dan meningkatkan jumlah kolagen pada tikus putih jantan galur Wistar (Rattus norvegicus) yang dipajan sinar UVB. Jenis penelitian ialah eksperimental murni dengan post test only control group design. Subjek penelitian ialah 30 ekor tikus putih jantan, galur Wistar (Rattus norvegicus), umur 2-3 bulan, dengan berat badan 120 gr yang dibagi menjadi 3 kelompok, masing-masing berjumlah 10 ekor tikus. Kelompok kontrol (P0) tidak dipapar sinar UVB; kelompok perlakuan 1 (P1) diberikan aquabides oral dan paparan sinar UVB; dan kelompok perlakuan 2 (P2) diberikan ekstrak kulit buah lemon oral dan paparan sinar UVB. Setelah 15 hari perlakuan, seluruh tikus dianestesi kemudian diambil jaringan kulitnya untuk dibuat preparat histologik dan dihitung jumlah kolagen dermisnya sebagai data post test. Hasil
\end{abstract}


analisis menunjukkan rerata jumlah ekspresi MMP1 pada kelompok P0 ialah 22,02 $\pm 3,20 \%$; kelompok P1 ialah 29,04 $\pm 6,36 \%$; dan kelompok P2 ialah 7,98 $\pm 2,76 \%(P<0,01)$. Rerata jumlah

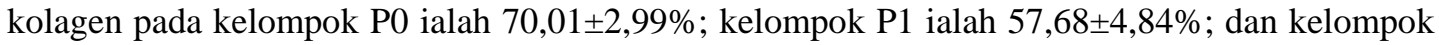
P2 ialah 77,45 $\pm 4,29 \%(P<0,01)$. Simpulan: Pemberian ekstrak kulit buah lemon per oral dapat menurunkan ekspresi MMP-1 dan meningkatkan jumlah kolagen pada tikus putih jantan galur Wistar (Rattus norvegicus) yang dipajan sinar UVB.

Kata kunci: kulit buah lemon, kolagen, MMP-1, UVB

Radiasi ultraviolet (UV) sinar matahari dapat mempercepat proses penuaan pada kulit, disebut sebagai photoaging. Proses ini bersifat kumulatif. Reaksi kronis dari pajanan sinar ultraviolet matahari selama bertahun-tahun dapat menimbulkan gangguan struktur kulit, dan terutama menyebabkan penuaan dini kulit, serta kanker kulit. ${ }^{1,2}$ Kerusakan yang ditimbulkan dapat dilihat baik secara klinis, histopatologik, maupun secara fungsional. ${ }^{3}$ Paparan radiasi UV sinar matahari menyebabkan kerusakan kulit melalui beberapa mekanisme, antara lain pembentukan sunburn cells, tercetusnya respon peradangan, terbentuknya thymine dimer, dan produksi matriks metaloproteinase (MMP). ${ }^{4}$ MMP adalah enzim proteinase mengandung $\mathrm{Zn}$ yang bertanggung jawab mendegradasi protein matriks ekstrasel. MMP diklasifikasikan sebagai kolagenase, gelatinase, stromyelisin, dan tipe membran. ${ }^{2}$ Sinar UV juga dapat memacu sintesis MMP-1 dan MMP-3 melalui pelepasan tumor necrosing factor-alpha (TNF- $\alpha)$ oleh keratinosit dan fibroblas, serta menyebabkan penurunan transforming growth factor-beta (TGF- $\beta)^{5}$ Pada kulit manusia, MMP-1 ialah tipe yang paling terpengaruh oleh induksi sinar UV matahari dan bertanggungjawab terhadap degradasi kolagen pada kulit yang mengalami photoaging. ${ }^{6}$

Dilaporkan bahwa hanya dengan satu kali terpapar radiasi UV sinar matahari dapat mengganggu jaringan ikat dengan menyebabkan gangguan sintesis kolagen yang hampir lengkap selama 24 jam kemudian diikuti dengan pemulihan 48-72 jam setelahnya. Selain itu juga terjadi degradasi kolagen karena peningkatan kadar MMP-1 yang cukup bermakna yaitu

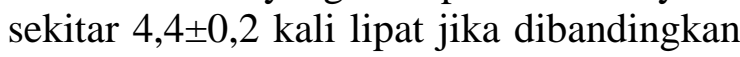

dengan kulit yang tidak dipajan radiasi UV. ${ }^{6}$

MMP-1 merupakan mediator utama terhadap terjadinya degradasi kolagen pada kulit yang mengalami photoaging. Dengan menghambat MMP-1 maka dapat dicegah kerusakan kulit akibat paparan sinar UV. Radiasi ultraviolet menghasilkan reactive oxygen species (ROS), dan bersama dengan aktivasi berbagai ROS-sensitive signaling pathways akan memengaruhi fungsi-fungsi selular termasuk menyebabkan fragmentasi kolagen dan sekresi MMP-1. ${ }^{7-9}$

Buah lemon sangat bermanfaat untuk kesehatan tubuh. Buah ini sangat kaya akan vitamin $\mathrm{C}$, magnesium, kalium, dan kalsium. Tidak hanya daging buahnya, kulit buah lemon juga memiliki kandungan antioksidan dan berfungsi sangat baik untuk menjaga kekebalan tubuh. Buah lemon sering juga digunakan sebagai bahan perawatan kulit wajah dengan memanfaatkan sari buah atau kulit lemon. Di Indonesia buah lemon bisa ditemukan di mana saja. Jeruk biasa bisa dimakan langsung karena memiliki kandungan gula, sedangkan lemon akan sangat masam bila dimakan tanpa campuran gula. Cairan buah lemon terdiri dari 5\% asam sitrat yang memberikan rasa khas lemon dan $\mathrm{pH}-$ nya sekitar 2-3. ${ }^{10}$

Hasil penelitian ini mendapatkan dosis optimal sebesar $40 \mathrm{mg}$. Dengan menggunakan dosis $40 \mathrm{mg}$ pada penelitian selanjutnya menunjukkan bahwa pemberian oral ekstrak kulit buah lemon yang banyak mengandung vitamin $\mathrm{C}$, vitamin $\mathrm{A}$, tanin, dan fenol dapat secara efektif menurunkan ekspresi MMP-1 dan meningkatkan jumlah kolagen pada tikus Wistar jantan yang dipajan sinar UVB dengan mengurangi dampak stres oksidatif. 


\section{METODE PENELITIAN}

Jenis penelitian ini ialah eksperimental murni dengan menggunakan randomized post test only control group design. Subyek penelitian ialah 30 ekor tikus putih (Rattus norvegicus), jantan, galur Wistar, berumur 2-3 bulan, dengan berat badan 120 gram yang terbagi menjadi 3 kelompok masingmasing berjumlah 10 ekor tikus. Kelompok kontrol (P0) tidak dipajan sinar UVB; kelompok perlakuan 1 (P1) diberikan aquabides oral dan pajanan sinar UVB; dan kelompok perlakuan 2 (P2) diberikan ekstrak kulit buah lemonper oral dan pajanan sinar UVB.

Persiapan penelitian meliputi adaptasi tikus dalam kondisi laboratorium selama 7 hari. Perlakuan berlangsung selama 15 hari. Pada kelompok P1 dan P2 diberikan pajanan sinar UVB melalui lampu TL UVB 20 Watt dengan frekuensi dua hari sekali selama 15 hari (hari ke-1,3,5,7,9,11,13, dan 15), dengan dosis pajanan sebesar 100 $\mathrm{mJ} / \mathrm{cm} 2$ per kali sehingga total pajanan sinar UVB yang diterima ialah 800 $\mathrm{mJ} / \mathrm{cm} 2$, dengan jarak penyinaran $20 \mathrm{~cm}$ dan lama penyinaran sekitar 100 detik. Pengukuran dosis pajanan dilakukan menggunakan alat UVmeter (Beltron,
Germany). Untuk menghindari efek penyinaran akut, biopsi kulit tikus dari ketiga kelompok diambil 24 jam setelah penyinaran terakhir dengan dieutanasia terlebih dahulu menggunakan ketamin dosis berlebih $(100 \mathrm{mg} / \mathrm{kgbb})$ secara intraperitoneal. Daerah punggung yang akan diambil kulitnya, dibersihkan dari bulu kemudian dibuat preparat histopatologik menggunakan pengecatan imunohistokimia (IHC) MMP-1 dan picro Sirius Red untuk kolagen.

\section{HASIL DAN BAHASAN}

Hasil penelitian menunjukkan rerata jumlah ekspresi MMP-1 pada kelompok kontrol (P0) yang tidak dipajan sinar UVB ialah 22,02 $\pm 3,20 \%$; pada kelompok perlakuan 1 (P1) yang diberikan aquabides oral dan pajanan sinar UVB ialah 29,04 $\pm 6,36 \%$; dan pada kelompok perlakuan 2 (P2) yang diberikan ekstrak kulit buah lemon oral dan pajanan sinar UVB ialah $7,98 \pm 2,76 \%(P<0,01)$. Rerata jumlah kolagen pada kelompok kontrol (P0) ialah 70,01 $\pm 2,99 \%$; pada kelompok perlakuan 1 (P1) ialah 57,68 $\pm 4,84 \%$; dan pada kelompok perlakuan 2 (P2) ialah 77,45 $\pm 4,29 \%(P<0,01)$ (Tabel 1).

Tabel 1. Rerata jumlah MMP-1 dan kolagen kulit antar kelompok

\begin{tabular}{clcccc}
\hline Variabel & \multicolumn{1}{c}{ Kelompok } & n & Rerata (\%) & $\boldsymbol{F}$ & $\boldsymbol{p}$ \\
\hline \multirow{3}{*}{ Ekspresi MMP-1 } & Kontrol (P0) & 10 & $22,02 \pm 3,20^{\mathrm{a}}$ & & \\
& Perlakuan 1 (P1) & 10 & $29,04 \pm 6,36^{\mathrm{b}}$ & 59,132 & 0,000 \\
& Perlakuan 2 (P2) & 10 & $7,98 \pm 2,76^{\mathrm{c}}$ & & \\
\hline \multirow{3}{*}{ Jumlah kolagen } & Kontrol (P0) & 10 & $70,01 \pm 2,99^{\mathrm{a}}$ & & \\
& Perlakuan 1 (P1) & 10 & $57,68 \pm 4,84^{\mathrm{b}}$ & 58,816 & 0,000 \\
& Perlakuan 2 (P2) & 10 & $77,45 \pm 4,29^{\mathrm{c}}$ & & \\
\hline
\end{tabular}

*Notasi $(\mathrm{a}, \mathrm{b}, \mathrm{c})$ yang berbeda menunjukkan berbeda bermakna $(P<0,05)$

Uji lanjutan untuk mengetahui perbedaan individual antar kelompok menggunakan Least Significance Difference (LSD) test menunjukkan bahwa terdapat perbedaan bermakna antara kelompok P0 dan kelompok P1; kelompok P1 dan P2; dan juga antara kelompok P0 dan $\mathrm{P} 2(P<0,01)$ baik pada variabel jumlah MMP-1 dan kolagen kulit.
Pemberian oral ekstrak kulit buah lemon ini dapat melindungi kulit dari kerusakan oksidatif yang diinduksi paparan ultraviolet karena ekstrak kulit buah lemon mengandung antioksidan yang cukup tinggi. Antioksidan dapat menghambat terbentuknya ROS, dan selanjutnya menghambat degradasi kolagen oleh pajanan sinar UVB dan meningkatkan 
jumlah kolagen dermis. Selain itu kandungan bahan aktif lainnya juga turut berperan dalam efek anti photoaging ini.

Buah lemon sangat bermanfaat untuk tubuh manusia. Buah lemon sangat kaya akan vitamin $\mathrm{C}$ (asam L-askorbat) yaitu antioksidan intrasel dan ekstrasel yang paling penting bagi tubuh. Vitamin C memberikan banyak manfaat bagi kulit, meningkatkan sintesis kolagen, dan bersifat fotoprotektor. Selain itu, vitamin C memiliki aktivitas antiinflamasi yang mendukung aktivitas fotoproteksinya. Vitamin C terbukti dapat memperbaiki kulit yang telah mengalami photodamage, meningkatkan sintesis kolagen, dan menghambat MMP-1 sehingga menurunkan keriput, dan menghambat tirosinase. ${ }^{11}$

Buah lemon juga banyak mengandung vitamin E yaitu sebesar 0,25 mg per 100 gram kulit lemon. Vitamin E sudah banyak digunakan dalam kosmetik diantaranya sebagai pelembab dan sebagai agen antioksidan. Vitamin E dapat mengurangi penuaan kulit akibat sinar matahari dan mencegah pembentukan sel kanker kulit, serta memelihara stabilitas jaringan ikat di dalam sel sehingga kelenturan dan kekenyalan kulit terjaga. ${ }^{12}$

Ekstrak kulit lemon mengandung polifenol yang dapat diberikan baik secara oral maupun topikal untuk mendapatkan efek fotoproteksi. Mekanisme antioksidan senyawa polifenol berdasarkan kemampuan mendonorkan atom hidrogen dan kemampuan mengelat ion-ion logam. Setelah mendonorkan satu atom hidrogen, senyawa fenolik menjadi senyawa yang stabil dan tidak mudah mengalami resonansi, sehingga tidak mudah berpartisipasi dalam reaksi radikal yang lain. ${ }^{13,14}$ Kulit lemon juga mengandung flavonoid yang merupakan suatu antioksidan golongan fenol yang banyak ditemukan di sayuran, buah-buahan, kulit pohon, akar, bunga, teh, dan wine. Konstribusi flavonoid untuk sistem pertahanan antioksidan sangat besar mengingat total asupan harian flavonoid dapat berkisar 50-800 $\mathrm{mg}$. Konsumsi ini lebih tinggi dibandingkan dengan rata-rata asupan harian diet antioksidan lain seperti vitamin C (70 mg), vitamin E (7-10 $\mathrm{mg}$ ), atau keratinoid (2-3 $\mathrm{mg}$ ). Flavonoid bisa mencegah kerusakan yang disebabkan oleh radikal bebas dengan beberapa cara, salah satunya ialah memusnahkan radikal bebas secara langsung. Flavonoid dioksidasi oleh radikal bebas, menghasilkan radikal yang lebih stabil dan kurang reaktif. Flavonoid dapat menstabilkan senyawa oksigen reaktif melalui reaksi dengan susunan reaktif dari radikal tersebut. ${ }^{14}$

\section{SIMPULAN}

Berdasarkan hasil penelitian dapat disimpulkan bahwa pemberian oral ekstrak kulit buah lemon dapat menurunkan ekspresi MMP-1 dan meningkatkan jumlah kolagen jaringan kulit tikus putih Wistar jantan yang dipajan sinar UV-B.

\section{DAFTAR PUSTAKA}

1. Walker SL, Hawk JLM, Young AR. Acute and chronic effects of ultraviolet radiation on the skin. In: Freedberg IM, Eisen AZ, Wolff K, Austen KF, Goldsmith LA, Katz SI, editors. Fitzpatrick's Dermatology in General Medicine (6th ed). New York: McGraw-Hill Medical Publishing Division, 2003; p. 1275-81.

2. Quan T, Qin Z, Xia W, Shao Y, Voorhees JJ, Fisher GJ. Matrix-degrading metalloproteinases in photoaging. $\mathbf{J}$ Invest Dermatol. 2009;14:20-4. Symposium Proceedings. Doi: 10.1038/jidsymp.2009.8

3. Berneburg M, Plettenberg H, Krutmann J. Photoaging of human skin. Photodermatol Photoimmunol Photomed. 2000;16:239-44.

4. Baumann L. Cosmetic and skin care in dermatology. In: Fitzpatrick TB, Wolff $\mathrm{K}$, editors. Dermatology in General Medicine. New York: Mc Graw-Hill, 2005; p. 2363-7.

5. Gilcherst BA, Krutman J. Skin Aging. Berlin: Springer-Verlag, 2006.

6. Fisher GJ, Choi HC, Csorgo ZB, Shao Y, Datta S, Wang ZQ, et al. Ultraviolet irradiation increases matrix metalloproteinase- 8 protein in human skin in vivo. $\mathrm{J}$ Invest Dermatol. 
2001;117:219-26.

7. Lee EH, Faulhaber D, Hanson KM, Ding W, Peters S, Kodali, S, et al. Dietary lutein reduces ultraviolet radiationinduced inflammation and immunosuppression. $\mathrm{J} \quad$ Invest Dermatol. 2004;122:510-7. Doi: 10.1046/j.0022-202X.2004.22227.x

8. Yaar M, Gilchrest BA. Photoaging: mechanism, prevention and therapy. British J Dermatol. 2007;157:874-87. Doi: $10.1111 / j .1365-$ 2133.2007.08108.

9. Helfrich YR, Sachs DL, Voorhees JJ. Overviews of skin aging and photoaging. Dermatol Nurs. 2008;20(3):177-83.

10. Hutasoit R. Buah Segar Musim. Jakarta: PT Gramedia Pustaka Utama, 2005.
11. Korać RR, Khambholja KM. Potential of herbs in skin protection from ultraviolet radiation. Pharmacognosy Reviews. 2011;5(10):164-73. Doi:10.4103/0973-7847.91114.

12. Trenggano, RIS, Latifah F, Djajadisastra J. Buku Pegangan Ilmu Pengetahuan Kosmetik. Jakarta: Gramedia Pustaka Utama, 2007; p: 81-3.

13. Chiu AE, Chan JL, Kern DG, Kohler S, Rehmus WE, Kimball AB. Doubleblinded, placebo-controlled trial of green tea extracts in the clinical and histologic appearance of photoaging skin. Dermatol surg, 2005;31:855-9.

14. Muchtadi TR, Sugiyono. Prinsip Proses dan Teknologi Pangan. Bandung: Alfabeta, 2013. 